\title{
Social Benefit Evaluation of Passive Design of Green Buildings
}

\author{
Shenghan $\mathrm{Li}^{1}{ }^{1, *}$, Lei Liu ${ }^{2}$ \\ ${ }^{1}$ College of Civil and Transportation Engineering, Shenzhen University, Shenzhen, Guangdong, 518000, China \\ ${ }^{2}$ College of Civil and Transportation Engineering, Shenzhen University, Shenzhen, Guangdong, 518000, China
}

\begin{abstract}
Passive design of green buildings has three benefits: economy, ecology and society. At present, there is no authoritative definition of social benefits at home and abroad, so it is very difficult to evaluate and measure. Based on Maslow's hierarchy of needs, economic and sociological theories, 5 first-level indicators and 20 second-level indicators of social benefit evaluation system for passive design of green buildings are obtained. In addition, the structural equation model was built by "AMOS" to analyze and compare these influencing factors. The research results showed that: Among the five latent variables, Environmental Effect is the most significant, followed by Sustainability, Economic Development Potential, Overall Measurement and People Oriented. And there is a significant positive impact between the latent variables. Among the secondary indicators, "Urban environment", "Enterprise investment environment", "Ecological environment policy", "Industrial scale and openness" and "Thermal comfort" are the main influencing indicators. Finally, some suggestions were put forward to provide reference for the evaluation of social benefit of related projects in the future.
\end{abstract}

\section{Introduction}

In recent years, with the acceleration of urban industrialization in China, urban building area has been increasing. The increasing demand for comfort of living environment leads to the increasing energy consumption, which makes the construction industry become a major energy consumer [1]. By 2015, the total area of construction had reached 59.193 billion square meters, and the total energy consumption of construction was 857 million tons of standard coal, accounting for $19.93 \%$ of the total national energy consumption [2]. Therefore, it is urgent to change the development mode of traditional construction industry and promote green buildings. Passive design concept in green buildings has become a trend of building energy-saving method [3].

At present, the evaluation system of economic and environmental benefits of passive design is perfect and its definition is very clear. However, scholars at home and abroad have not reached a general consensus on the definition of social benefit, so it is still a hot and difficult topic in the current academic discussion [4]. Gao, X. L.(2008) based on analytic hierarchy process (AHP) and matrix evaluation method, constructed a comprehensive evaluation system for the economic, social, environmental and technical benefits of energy-saving residential buildings, and made an empirical analysis on the integration of solar hot water and buildings and the combination of solar photovoltaic engineering and buildings [5]. Yang, C. X.(2011) established a comprehensive evaluation system of the whole life cycle process from decision-making stage to demolition and reuse stage for a green building in an ecological city of
Tianjin. And the social benefits are analyzed in detail [6]. Yin, B. G.(2014) obtains the evaluation system of social benefit of Passivhaus, and makes empirical analysis to verify the effectiveness and scientificity of the index [7]. Liu, X. J.(2012) divides the benefit evaluation system of green building into explicit and invisible benefits. The invisible benefits includes social and economic benefits, and the social benefits are elaborated from the micro and macro perspectives [8]. Zhang, D.W. et al. (2015) analyzed the social benefits of energy-efficient buildings, pointed out the unreasonable energy structure of domestic buildings and other energy consumption problems, discussed the social benefits from the perspective of all participants, and put forward corresponding solutions [9].

Through combing the above literatures, the social benefit evaluation of energy-saving buildings has made some progress, but there is no consensus on the social benefit of the passive design. So it need to be further improved and explored.

\section{Evaluation system of social benefit}

Through the previous analysis, this paper argues that social benefit is a kind of social evaluation, which clarifies the effects and benefits of related projects from the perspective of society. It requires us to systematically know the relationship between the object of study and various social factors. The author comprehensively examines the social economy and rationality of passive design from Maslow's hierarchy of needs theory, economic and sociological theory. Finally, the social

\footnotetext{
* Corresponding author: 497948146@qq.com
} 
benefits of passive design are analyzed, which are composed of five factors: People-oriented, Sustainability, Environmental effect, Economic development potential and Overall measurement, as shown in Fig 1. Each influencing factor is analyzed and corresponding indicators are obtained, as shown in Table 1.

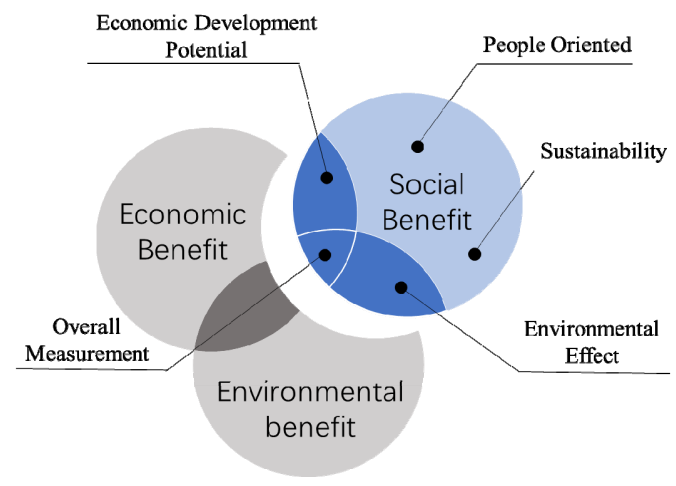

Fig. 1. Scope and influencing factors of social benefits

Table 1. Social benefit evaluation system of passive design

\begin{tabular}{|c|c|}
\hline $\begin{array}{c}\text { Latent Variable } \\
\text { (first order) }\end{array}$ & Observable Variable \\
\hline People Oriented & $\begin{array}{l}\text { Thermal comfort } \\
\text { Indoor health } \\
\text { Public participation } \\
\text { Science and education } \\
\text { Living standard of residents }\end{array}$ \\
\hline Sustainability & $\begin{array}{l}\text { Industrial technology innovation } \\
\text { Construction cost } \\
\text { Energy-saving and emission- } \\
\text { reduction } \\
\text { Regional cultural impact }\end{array}$ \\
\hline $\begin{array}{l}\text { Environmental } \\
\text { Effect }\end{array}$ & $\begin{array}{l}\text { Indoor environment } \\
\text { Urban environment } \\
\text { Aesthetic benefit } \\
\text { Enterprise investment environment }\end{array}$ \\
\hline $\begin{array}{l}\text { Economic } \\
\text { Development }\end{array}$ & $\begin{array}{l}\text { Industrial structure optimization } \\
\text { Industrial scale and openness } \\
\text { Employment benefit }\end{array}$ \\
\hline & $\begin{array}{l}\text { Coordination of related industries } \\
\text { National green development policy }\end{array}$ \\
\hline $\begin{array}{c}\text { Overall } \\
\text { Measurement }\end{array}$ & $\begin{array}{l}\text { Regional development policy } \\
\text { Ecological protection policy }\end{array}$ \\
\hline
\end{tabular}

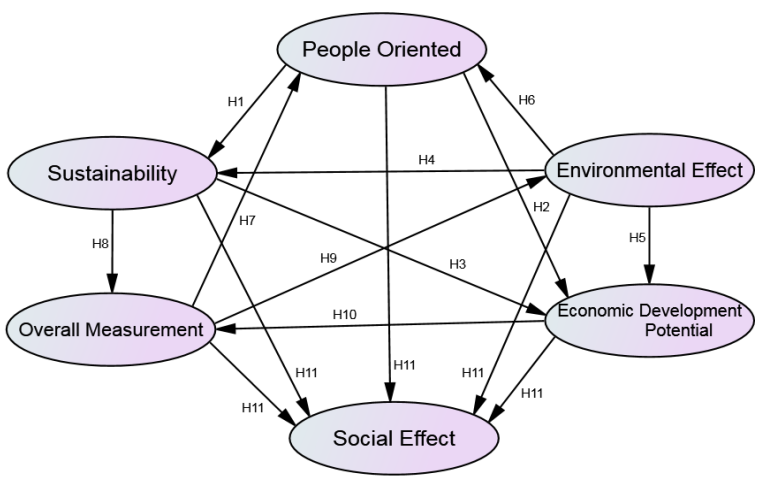

Fig. 2. The structural model

\section{Empirical study based on SEM}

\subsection{Constructing the theoretical model}

The traditional measurement methods have some limitations in multi-variable relationships, and structural equation can deal with latent variables and their indicators at the same time. Therefore, structural equation model was established by "AMOS" to analyze the relationship between them, which consists of two parts: (1) measurement model hypothesis. (2) structure model hypothesis(H1-H11), as shown in Fig. 2.

\subsection{Reliability and Validity Analysis}

The Krenbach alpha coefficient of internal consistency reliability is used to test the reliability, stability and consistency. The specific results are shown in table 2 . The total Cronbach's alpha is $0.946(>0.7)$, and Cronbach's alpha of each sub-item was larger than 0.7. So the overall reliability of the questionnaire was relatively high and reached the acceptable standard, which could be further analyzed for validity.

Table 2. Reliability test results

\begin{tabular}{ccc}
\hline Latent Variable & Index Quantity & Cronbach's $\alpha$ \\
\hline People Oriented & 5 & 0.826 \\
Sustainability & 4 & 0.810 \\
Environmental Effect & 4 & 0.857 \\
Economic & 4 & 0.839 \\
Development Potential & 3 & 0.863 \\
\hline Overall Measurement & $\mathbf{2 0}$ & $\mathbf{0 . 9 4 6}$ \\
\hline Total &
\end{tabular}

KMO value and bartlett spherical test are adopted in the academic circle to test whether the questionnaire is suitable for factor analysis and then validity test. The results of KMO and Bartlett sphericity test in this scale are shown in table 3 . The $\mathrm{KMO}$ value is $0.932(>0.9)$, and the $\mathrm{P}$ value of Bartlett sphericity test is $0(<0.05)$. The test results are significant, indicating that there is a strong correlation between research variables and factor analysis is effective.

Table 3. Bartlett's Test

\begin{tabular}{|c|c|c|}
\hline $\begin{array}{r}\text { Kalser-Meyer-Olk } \\
\text { A }\end{array}$ & $\begin{array}{l}\text { Measure of Sampling } \\
\text { quacy }\end{array}$ & 0.932 \\
\hline \multirow{3}{*}{$\begin{array}{l}\text { Bartlett's Test of } \\
\text { Sphericity }\end{array}$} & Approx. Chi-Square & 2836.610 \\
\hline & $\mathrm{df}$ & 190 \\
\hline & Sig. & .000 \\
\hline
\end{tabular}

Since the dimensions had been determined through a large number of literatures in this study, confirmatory factor analysis was used for the validity analysis. The confirmatory factor analysis model was established by AMOS22.0. The results showed that $x^{2} / \mathrm{df}=2.768<3$, RMSEA $=0.072>0.08$, indicating that the confirmatory factor analysis model has a good fitting effect, and then 
the convergent validity and discriminant validity are further analyzed.

It can be seen from table 4 that the combined reliability $(\mathrm{CR})$ of all potential variables is greater than 0.6 (minimum value of 0.822 ), and the average variance sampling (AVE) is greater than 0.5 (minimum value of 0.504 ), indicating that the measurement scale has good polymerization validity. In Table 5 , the values on the diagonal line are the average variance extraction of the corresponding potential variables, and the other values are the square of the correlation coefficients of the potential variables. The average variance extraction of the potential variables is larger than the square of the correlation coefficients of the variables and other variables, which indicates that the potential variables in the measurement scale have good discriminatory validity. Therefore, it can be considered that the overall validity of the scale is good.

Table 4. Convergent validity

\begin{tabular}{ccc}
\hline Factor & AVE & CR \\
\hline People Oriented & 0.504 & 0.834 \\
Sustainability & 0.537 & 0.822 \\
Environmental Effect & 0.602 & 0.858 \\
Economic Development Potential & 0.600 & 0.856 \\
Overall Measurement & 0.695 & 0.872 \\
\hline
\end{tabular}

Table 5. Discriminant validity

\begin{tabular}{c|ccccc}
\hline Factor & EE & EDP & PO & OM & SU \\
\hline EE & 0.344 & & & & \\
EDP & 0.336 & 0.403 & & & \\
PO & 0.238 & 0.245 & 0.305 & & \\
OM & 0.293 & 0.345 & 0.196 & 0.408 & \\
SU & 0.316 & 0.319 & 0.262 & 0.301 & 0.332 \\
\hline
\end{tabular}

\subsection{Confirmatory Factor Analysis}

After the reliability and validity analysis, the structural equation model of the first order confirmatory factor analysis is established in combination with the research hypothesis proposed above. Then, through the derivation and calculation of the fitting function value, it is found that the fitting effect of the model is not good, so the model needs to be modified. According to the estimation results of model parameters, the assumed paths with $\mathrm{P}$ value greater than 0.05 were deleted, including Economic Development Potential <-- People Oriented, Economic Development Potential <-- sustainability, People Oriented <--Overall Measurement, Overall Measurement $<$-Sustainability and Environmental Effect<--Overall Measurement. In addition, from the revised index of Amos 22.0 output, there are relatively high correction indexes between "public participation" and "science and education", between "science and education" and "Living standard of residents", between "indoor environment" and "urban environment", so it need to add paths E3 < -- > E4 < -- > e5, E13 < -- > e14. After modification,the structural equation model of the first order confirmatory factor analysis which meets the requirements of evaluation criteria is finally obtained, as shown in Fig 3. The results of model evaluation are shown in Table 6.

In the structural equation model, the social benefit evaluation of passive design is a second-order confirmatory factor model, which is predicted by five potential variables. On the basis of the above first-order confirmatory factor analysis, it is necessary to further verify the path coefficients of five latent variables to the social benefit of passive design. The second-order confirmatory factor analysis structure model is obtained by Amos 22.0, as shown in Fig. 4.

The normalized path coefficient $(\beta)$ and those fitting indexes, such as $\times 2 / \mathrm{df}=2.327<3$, RMSEA $=0.056<$ 0.08 , showed that the model fitted well. Then, according to the parameter estimates of the second-order confirmatory factor analysis (Table 7), it can see that the $\mathrm{CR}$ values of the five latent variables are greater than 1.96 and the $\mathrm{P}$ values are all three stars, indicating that each path has reached a significant level of 0.001 . The relationship between the factors and the social benefit is obvious, which can fully express the social benefits of passive design of green buildings. Finally, according to the three parameters of $\beta, C R$ and $P$, the verification results of all research hypotheses proposed above are obtained, as shown in Table 8.

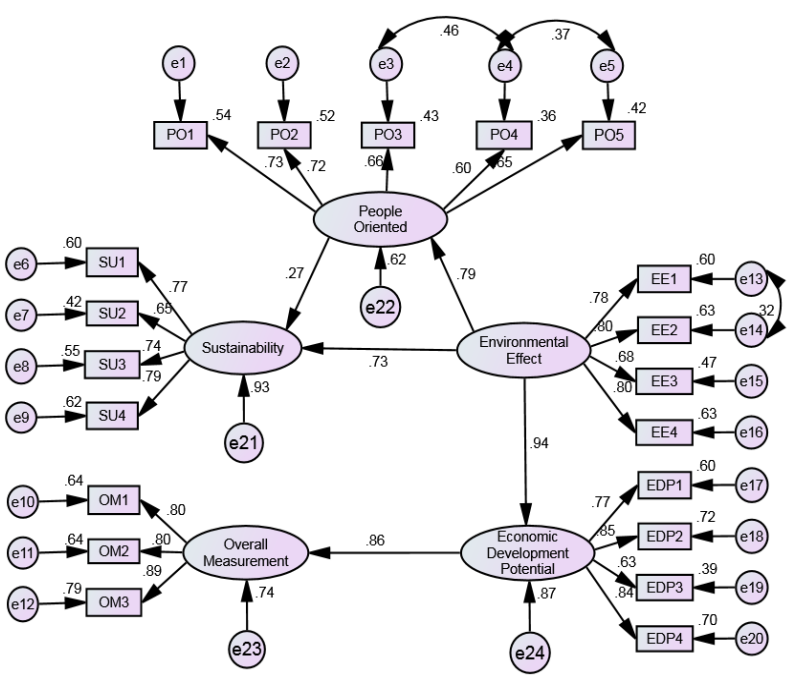

Fig. 3. First-order confirmatory factor analysis

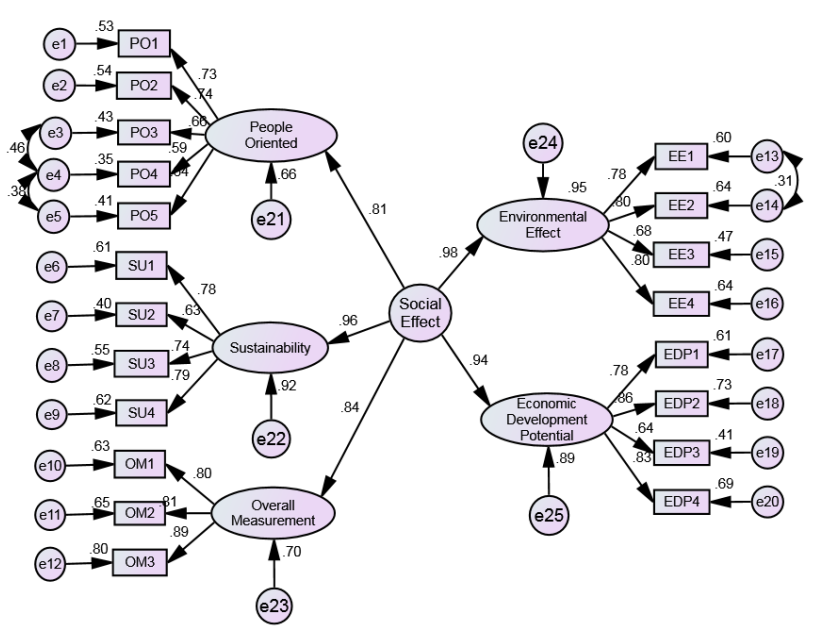

Fig. 4. Second-order confirmatory factor analysis 
Table 6. Model evaluation results

\begin{tabular}{|c|c|c|c|}
\hline Fitting index & $\begin{array}{c}\text { evaluation } \\
\text { criteria }\end{array}$ & $\begin{array}{c}\text { Initial test } \\
\text { data }\end{array}$ & $\begin{array}{c}\text { Corrected test } \\
\text { data }\end{array}$ \\
\hline $2 / \mathrm{df}$ & $1<2 / \mathrm{df}<3$ & 2.768 & 2.082 \\
\hline RMR & $<0.05$ & 0.38 & 0.033 \\
\hline RMSEA & $<0.08$ & 0.092 & 0.042 \\
\hline GFI & $\geq 0.90$ & 0.824 & 0.926 \\
\hline AGFI & $\geq 0.90$ & 0.769 & 0.915 \\
\hline IFI & $\geq 0.90$ & 0.898 & 0.941 \\
\hline CFI & $\geq 0.90$ & 0.897 & 0.94 \\
\hline
\end{tabular}

Table 7. Parameter estimation

\begin{tabular}{cccccc}
\hline & Estimate & S.E. & C.R. & P & $\begin{array}{c}\text { Standardized } \\
\text { Estimate }\end{array}$ \\
\hline EDP <-- & 1 & & & $* * *$ & 0.944 \\
SU <-- Social & 0.907 & 0.081 & 11.144 & $* * *$ & 0.961 \\
OM <-- & 0.898 & 0.081 & 11.043 & $* * *$ & 0.839 \\
EE <-- effect & 0.912 & 0.076 & 11.973 & $* * *$ & 0.977 \\
PO <-- & 0.79 & 0.084 & 9.403 & $* * *$ & 0.809 \\
\hline
\end{tabular}

Table 8. Verification results of research hypothesis

\begin{tabular}{|c|c|c|}
\hline & Hypothetical & $\begin{array}{l}\text { Yes } \\
\text { /No }\end{array}$ \\
\hline $\mathrm{H} 1$ & $\begin{array}{l}\text { "People Oriented" has a significant positive impact } \\
\text { on "Sustainability" }(0.27)\end{array}$ & $\mathbf{Y}$ \\
\hline $\mathrm{H} 2$ & $\begin{array}{l}\text { "People-Oriented" has a significant positive impact } \\
\text { on "Economic Development Potential" }\end{array}$ & $\mathbf{N}$ \\
\hline $\mathrm{H} 3$ & $\begin{array}{l}\text { "Sustainability" has a significant positive impact on } \\
\text { "Economic Development Potential" }\end{array}$ & $\mathbf{N}$ \\
\hline $\mathrm{H} 4$ & $\begin{array}{l}\text { "Environmental Effect" has a significant positive } \\
\text { impact on "Sustainability"(0.73) }\end{array}$ & $\mathbf{Y}$ \\
\hline H5 & $\begin{array}{l}\text { "Environmental Effect" has a significant positive } \\
\text { impact on "Economic Development Potential" } \\
(0.94)\end{array}$ & $\mathbf{Y}$ \\
\hline H6 & $\begin{array}{l}\text { "Environmental Effect" has a significant positive } \\
\text { impact on "People Oriented" ( } 0.79)\end{array}$ & $\mathbf{Y}$ \\
\hline $\mathrm{H} 7$ & $\begin{array}{l}\text { "Overall Measurement" has a significant positive } \\
\text { impact on "People Oriented" }\end{array}$ & $\mathbf{N}$ \\
\hline $\mathrm{H} 8$ & $\begin{array}{l}\text { "Sustainability" has a significant positive impact on } \\
\text { "Overall Measurement" }\end{array}$ & $\mathbf{N}$ \\
\hline H9 & $\begin{array}{l}\text { "Overall Measurement" has a significant positive } \\
\text { impact on "Environmental Effect" }\end{array}$ & $\mathbf{N}$ \\
\hline H10 & $\begin{array}{l}\text { "Economic Development Potential" has a significant } \\
\text { positive impact on "Overall Measurement" }(0.86)\end{array}$ & $\mathbf{Y}$ \\
\hline & $\begin{array}{l}\text { People Oriented( } 0.81) \text {, Sustainability }(0.95) \text {, } \\
\text { Environmental Effect }(0.96) \text {, Economic Development }\end{array}$ & \\
\hline H11 & $\begin{array}{l}\text { Potential }(0.94) \text {, Overall Measurement }(0.84) \text { has a } \\
\text { significant positive impact on Social Benefits of } \\
\text { Passive Design of Green Buildings }\end{array}$ & $\mathbf{Y}$ \\
\hline
\end{tabular}

\section{Conclusions}

Theoretically, this paper explores the social benefits of passive design of green buildings from five aspects. Through the first order confirmatory factor analysis, the influence relationship between latent variables and latent variables, latent variables and observed variables is obtained. Then, through second-order confirmatory factor analysis, the influences of latent variables on the social benefits of passive design are obtained, and it can be found that Environmental Effect have the most significant influence on the social benefits of passive design ( $\beta=0.96)$, followed by Sustainability ( $\beta=0.95$ ), Economic Development Potential ( $\beta=0.94)$, Overall Measurement ( $\beta=0.84$ ) and People Oriented ( $\beta=0.81$ ). Finally, according to the analysis results of the structural equation model, the five influencing dimensions are analyzed in detail:

1) Among the environmental impact indicators, the most important one is the degree of urban environmental optimization and the impact of enterprise investment environment. The path coefficient is $0.80(>0.8)$. This shows that it is important to improve the urban construction environment, reduce air pollution and heat island effect, and optimize the investment environment of enterprises in related industries, which coincides with the development planning ideas of general emerging industries.

2) For sustainable development, the most important thing is to reduce construction costs by increasing innovation and inventing more advanced passive technology, so that ordinary people can also benefit from the convenience of advanced technology. Moreover, it makes the area have a certain influence of architectural culture and improves the local popularity. All the relevant index paths were higher than 0.7 , which had a great impact.

3) From the perspective of economic development potential, the expansion of industrial development scale and higher openness to society have a significant impact on economic development. Its path coefficient is 0.85 . Only when it is more inclusive and open to the society and the industrial structure is more reasonable, can it expand its market scale, get economic returns and promote social and economic development.

4) From the perspective of policy comprehensiveness, ecological environmental policy has the greatest influence, with the path coefficient of 0.89. And the national green development policy and the regional development policy also have a greater impact, which path coefficient is 0.8 . It shows that the policy is important for the development of passive design technologies. Therefore, it needs to vigorously develop the passive design technologies of green buildings through policy support.

5) Among the People Oriented indicators, the indoor thermal comfort and human health has a significant impact, with path coefficients of 0.73 and 0.72 respectively. It shows that the feeling of the service object of passive design technology is very important. Only by making the residents more comfortable and healthy in the indoor environment, can the development of passive design technology have wide public support.

\section{References}

1. E. Z. Hou, BEE (Dec. 2017), 131.

2. W. Liu, DAW(Feb. 2017), 26-29. 
3. X. Chen, H. Yang, L. Lu. RSE 50, 1425-1436. (2015).

4. S. F. Ke, L. F. Zhu, FE(Mar. 2018), 65-70+76.

5. X. L. Cao, J. P. Wang, CE(Nov. 2008). 100-103.

6. C. X. Yang, Beijing University of Civil Engineering and Architecture (2011).
7. B. G. Yin, Xi'an University of Architecture and Technology (2014).

8. X. J. Liu, Beijing Jiaotong University (2012).

9. D. W. Zhang, MAT (Jan. 2015). 